\title{
CONTROL AND SUPERVISORY AUTHORITIES OF CENTRAL BANKS
}

\section{Marushchak A. V.}

\section{INTRODUCTION}

It can be stated that in all countries with a market economy, a system of banking control and supervision operates in one form or another. Some of them have been around for over a century. In the post-socialist countries, the banking sector has been reformed in recent decades, and establishment of its supervision and oversight system has been an integral part this process. At the same time, in some countries with mature banking traditions significant changes can be seen in the concepts of building these systems, especially towards activity expansion, which involves globalization of banking activity and increasing risk of banks mastering new financial instruments and nontraditional operations( such as insurance, real estate, etc.). The institutional structure of the banking supervision system is determined by the peculiarities of historical and economic development of a country, the traditions and, to a large extent, the nature of the banking system itself. Thus, in the UK, due to the absence of antitrust laws and tight controls on the merger of banks, a high degree of bank capital concentration was achieved. Large banking associations were formed with a well-developed network of branches in the country and abroad, which concentrated a considerable share of resources, operations, and non-cash movement. The banking system concentration led to centralization of regulations and supervision functions in a single institution, the Bank of England. The situation turned out different in the USA. Unlike in the United Kingdom, many small, non-affiliated banks have remained in the United States. Therefore, there are different models of institutional patterns in the banking supervision system across the globe, but it is of great importance for all of them that the supervisory authorities have all the necessary powers for the effective fulfillment of their tasks.

In addition, these powers should be provided at the legislative level.

Banking supervision is aimed at maintaining the stability, reliability and efficient operation of certain components of the country's financial and banking system, primarily banks themselves. The purpose of such activity is to ensure the stable, normal functioning of the entire banking system ${ }^{1}$. The experience of many countries shows that under proper management, banks can survive even in adverse economic conditions.

\footnotetext{
${ }^{1}$ Качан О.О. Банківське право.К. : Юрінком Інтер, 2000. С. 37-38.
} 
At the initial stage of its development, the system of regulating the activities of banking institutions was created in specific countries independently. Each country tried to mantain the above activities separately from the other. The conditions of banking supervision are laid down, as a rule, in legislative acts regulating the status of the central bank. Banking regulations and supervision are part of the state central bank powers ${ }^{2}$. Due to the fact that the function of banking regulation and supervision is to create a safe and sound banking system and to prevent the instability of the financial system as a whole, the central bank, as an institution that administers monetary policy and a last resort lender, is a natural center of banking supervision.

However, the development of global economic ties and the integration of national banking systems have raised new challenges for counties to implement banking regulation and banking supervision. The impact of global trends on national banking markets has forced countries to find a way out of the situation.

\section{Control and supervisory authorities of central banks of the countries with romano-german legal system}

After World War II, a number of Central European countries disposed to monitor and coordinate the activities of commercial banks on a common basis. This was due to the internationalization of banking industry.

The bankruptcy of West Bankhaus Herstat in 1974 ensuing currency and other losses had devastating effects on the global interbank market and drew attention to the liability of international cooperation expansion in banking control and bringing it to a new level. Later, under the auspices of the Bank of International Settlements this led to the formation of the Committee on Banking Regulation and Supervisory Practices, which was called the Basel Committee at located in the Swiss city of Basel. The committee included representatives of the banking supervisory authorities and central banks of the Big Ten countries (Belgium, Canada, France, Germany, Italy, Japan, the Netherlands, Sweden, the United Kingdom, the United States), as well as Switzerland and Luxembourg.

The most important result of the Basel Committee activity can be considered as the principles of effective banking supervision it developed. According to the Basel Committee, achieving compliance with the basic principles of each country will be an important step towards improving both national and international financial stability ${ }^{3}$. Effective banking supervision,

2 Костюченко О.А. Банківське право: Банківська система. Національний банк. Комерційні банки. Розрахунки і кредитування. Ринок цінних паперів. Національне валютне законодавство. Банківські системи зарубіжних країн. Інститут банківської таємниці : підручник. 3-тє вид. К. : Видавництво А.С.К., 2003. 928 с.

3 Поляков В. П., Московкина Л. А. Структура и функции центральных банков (зарубежный опыт) : учеб. пособ.М. : ИНФРА-М,1995. 192 с. 
together with sound macroeconomic policies, should be major tools for ensuring financial stability in each country.

The Committee was guided by two main principles:

1) no banking system should remain outside the banking supervision system; 2) supervision must be reliable.

The organization of the banking supervision system is based stands upon the level of the central bank independence , its ownership and national traditions set during the formation of banking system.

According to V.P. Polyakov and L.A. Moscowkina, the functions of the central bank can be classified as primary and secondary. The main functions are those without it is impossible to perform the main task of the central bank - to maintain the stability of the national currency, and additional ones are those that meet the task implementation requirements. The authors divide main functions into regulating, controlling and servicing ${ }^{4}$. Regulatory functions, which are closely related to the conduct of monetary policy, include: 1) managing the aggregate monetary turnover in the country; 2) regulation of the financial ; 3) regulation of supply and demand for credit. The control functions include: a) control over the functioning of the credit and banking system; b) organization of the banking supervision system; c) conducting currency control. The service functions are: 1) organization of payment and settlement relations within the system; 2) the role of the central bank as the government agent. Additional central bank functions are not directly related to monetary policy.for the most part, they include: providing services to a client through establishing correspondent relations with other banks; representation of the state in international relations, where cooperation is carried out between central banks; tracking trends in supply and demand for cash etc. These functional divisions are as well investigated by other authors ${ }^{5}$.

Based on the foregoing, all of these functions are inherent in central banks in advanced market economies where a two-tier banking system operates. Moreover, the functions that outline the features of the central bank are the product of the bank operational evolution , based on a long historical process of gradually concentrating the right to issue banknotes, as well as obligations to serve the government in the most reliable banks (for example, this process is traced in one of the oldest central banks in the world - the Bank of England). Nevertheless, despite the fact that in some countries the creation of the central bank was accompanied by the adoption of a relevant legal act

${ }^{4}$ Поляков В. П., Московкина Л. А. Структура и функции центральных банков (зарубежный опыт) : учеб. пособ.М. : ИНФРА-М,1995. 192 с.

${ }^{5}$ Міщенко В. І. Центральні банки: організаційно-правові засади. К. : Тов. «Знання», 2004. $372 \mathrm{c}$. 
(for example, the US Federal Reserve)such a process has undergone a certain historical path of development, as its core ${ }^{6}$.

Modern civil law is a statutory right, it is hierarchical. The constitutions and other laws written there have an overriding priority in the national system of law, and jurisprudence in some countries, such as France, is defined by a source of law, but not the same way the jurisprudence in England (although, as noted in certain circumstances, the decisions of the cassation court or the State Council often play a role in the legal life of France no less than the law). In England, the principles of law and legal doctrine are defined as sources of law. An important feature of the legal systems of the countries with RomanoGerman legal system is the differentiation of the law to public and private. Concurrently, public law, as well as the private, is divided in all countries of this legal family into the samekey branches: constitutional law, administrative law, international public law, criminal law, criminal procedural law, etc.

The German central bank model is fundamental in Central European countries. Former Bundesbank President G. Schlesinger, in 1991, called out all European central banks to be independent, to grant them full autonomy in monetary policy so that they could maintain price stability, regardless of the governmental measures and regulations.

Key features of the Bundesbank: issue of banknotes; operations with gold and foreign exchange devices; cash execution of the budget; government and international lending; accounting policy; bank reserves and money supply regulation etc.

In recent years, banking in Germany has been and is still remains the subject of dramatic regulatory changes. The German banking system consists of three components: private commercial banks, public savings banks and cooperative banks. While commercial banks operate throughout the country, savings and cooperative banks tend to function on a regional basis only. Owing to their regional focus, most of these banks are relatively small, so implementing regulatory requirements is often more difficult for them.

The German banks are under control of the state, namely the Financial Supervisory Authority (Bundesanstalt für Finanzdienstleistungsaufsicht"BaFin") and the German Federal Bank (Bundesbank) ${ }^{7}$. BaFin is responsible for taking any supervisory measures, such as granting or revoking a license. The Bundesbank is responsible for obtaining and analyzing data submitted by banks. Both bodies cooperate closely. However, the final decision on the supervisory measures is taken by BaFin.

${ }^{6}$ Латковська Т. А. Основні функції центрального банку: проблеми визначення та класифікації. Актуальні проблеми держави і права. 2011. Вип. 61. С. 218-227.

${ }^{7}$ R. K. "Regulation", «Global Legal Insights» 03/06/2013: http://www.globallegalinsights. com/practice-areas/banking-and-finance/banking-regulation-1st-ed/germany. 
The regulatory system in Europe is now likely to be the subject of fundamental changes. They are triggered by a political initiative to create a banking union across the EU. On 12 September 2012, the European Commission presented a proposal for the transfer of key competences of national supervisory authorities to the European Central Bank ("ECB"). This transfer is aimed at centralizing the administrative standards of banking supervision in the European Union through a single control mechanism ("SSM") under the responsibility of the ECB. These proposals were discussed in the so-called "Trialog" between the European Commission, the Council of Ministers and the European Parliament. On March 25, 2013, Trialog approved a project to establish a Governing Council for the prudential policy of credit institutions. The draft resolution was adopted on the basis of Art. 127 paragraph 6 of the Treaty on the Functioning of the European Union ("TFEU") ${ }^{8}$. The legislative procedure requires the consent of all 27 Member Countries of the European Union.

According to the draft regulation, the ECB has the right to entrust the national regulator with certain management decisions. As a result, the supervisory responsibilities of BaFin and the Bundesbank are significantly reduced.

Germany is a Member Country of the European Union and thus takes into account most of the EU financial supervision legislation, namely Directive 2006/48 ${ }^{9}$, Capital Adequacy Directive ${ }^{10}$, Markets in Financial Instruments Directive $^{11}$, Directive on the powers of the European Financial Supervisory Authorities, the Payments Directive ${ }^{12}$, E-Money $^{13}$, and the UCITS Directive ${ }^{14}$.

${ }^{8}$ The Lisbon Treaty Treaty on the Functioning of the European Union \& comments Part 3 / Union policies and internal actions Title VIII - Economic and monetary policy (Articles 119-144) Chapter 2 - Monetary policy Article 127: http://www.lisbon-treaty.org/wcm/ the-lisbon-treaty/treaty-on-the-functioning-of-the-european-union-and-comments/part-3-unionpolicies-and-internal-actions/title-viii-economic-and-monetary-policy/chapter-2-monetarypolicy/395-article-127.htm.

9 DIRECTIVE 2006/48/EC OF THE EUROPEAN PARLIAMENT AND OF THE COUNCIL: http://eur-lex.europa.eu/legal-content/EN/TXT/?uri=CELEX:32006L0048.

${ }^{10}$ DIRECTIVE 2006/49/EC OF THE EUROPEAN PARLIAMENT AND OF THE COUNCIL: http://eur-lex.europa.eu/legal-content/EN/TXT/?uri=celex:32006L0049.

11 Directive 2004/39/EC of the European Parliament and of the Council: http://eur-lex.europa.eu/legal-content/EN/TXT/?uri=celex:32004L0039.

12 DIRECTIVE 2007/64/EC OF THE EUROPEAN PARLIAMENT AND OF THE COUNCIL: http://eur-lex.europa.eu/LexUriServ/LexUriServ.do?uri=OJ:L:2007:319:0001: 0036:en:PDF.

13 DIRECTIVE 2009/110/EC OF THE EUROPEAN PARLIAMENT AND OF THE COUNCIL: http://eur-lex.europa.eu/LexUriServ/LexUriServ.do?uri=OJ:L:2009:267: 0007:0017:EN:PDF.

14 DIRECTIVE 2009/65/EC OF THE EUROPEAN PARLIAMENT AND OF THE COUNCIL: http://eur-lex.europa.eu/LexUriServ/LexUriServ.do?uri=OJ:L:2009:302:0032: 0096:en:PDF. 
The basic provisions of German banking supervision are laid down in the Law on German Banking (Kreditwesengesetz - "KWG"15). KWG sets out the requirements and responsibilities to be fulfilled by banks and other institutions.Other than that, it sets out capital requirements and liquidity requirements. The law also establishes certain organizational responsibilities for management and internal control systems. This defines the competence and authority of BaFin and the Bundesbank, and contains provisions for dealing with institutions that are insolvent or undergoing the times of financial crisis.

In addition to KWG, there are a number of other laws governing the financial sector of Germany through the Bundesbank. One of those is the supervisory law (Zahlungsdiensteaufsichtsgesetz "ZAG"), which covers the supervision of payment services and implements the European Payment Services Directive. The following is the Investmentgesetz "INVG" law, which covers the provision of investment services and implements the UCITS European Directive. The provision of services related to securities and financial instruments is subjected to the Securities Trading Act (Wertpapierhandelsgesetz, "WpHG") implemented by the Bundesbank. The German "Pfandbriefe" (a special type of covered bond) is liable to the Pfandbrief Law (Pfandbriefgesetz, "PfandBG"). These are followed by ancillary regulations and regulations, most of which detail specific regulatory aspects. For example, information on capital requirements is set out in Solvabilitätsverordnung, SolvVO, and Liquiditätsverordnung, LiqV.

In addition to the laws, the Bundesbank publishes numerous acts, explanatory notes and decisions concerning certain aspects of the regulatory law.

In Bulgaria, which is a typical representative of the Romano-German legal family, the Central Bank (BNB) is one of the oldest banking institutions in Europe, established in 1879. The BNB holds important regulatory and monetary oversight powers (primarily for banks). as credit institutions).

The BNB, unlike the German Bundesbank, is the only supervisory body for banks. Its role is explicitly stated in Law on the Bulgarian National Bank (LoBNB) ${ }^{16}$ : "The Bulgarian National Bank regulates and controls activities in its country to ensure the stability of the banking system and to protect depositors of other banks."

The supervision of credit institutions in Bulgaria is one of the main functions of the BNB, which is aimed at maintaining the stability of the banking system and protecting the interests of depositors. Bulgaria's banking system is the subject of a legislative framework for the implementation of

${ }^{15}$ Gesetz über das Kreditwesen (Kreditwesengesetz - KWG): http://www.gesetze-iminternet.de/bundesrecht/kredwg/gesamt.pdf.

${ }^{16}$ Law on the Bulgarian National Bank: http://www.bnb.bg/bnbweb/groups/public/ documents/bnb_law/laws_bnb_en.pdf. 
Basel III in the European Union. These requirements are outlined in the CRD IV Package, effective January 1, 2014.

Prior to operating in Bulgaria, each bank must obtain a license from the National Bank. To do this, the bank, its shareholders and members of management and boards (or boards of directors) must meet the requirements set out in the LCI.

The National Bank monitors each of the credit institutions on the basis of regulatory reports and audits, covering the financial position and managing the risks inherent in credit and other activities.

At the micro level, supervision is to ensure that each bank operates safely and has sufficient capital, reserves to prevent the risks associated with its operations. At the same time, the BNB conducts research and analysis of developments, trends in the banking sector as a whole (macroeconomic level), aiming to of prevent and reduce the systemic risk, while avoiding adverse effects in the sector, which provides a sustainable economic growth.

Banking supervision also focuses on compliance with other regulatory requirements such as money laundering, terrorist financing and fraud. The BNB monitors the existence of adequate procedures in banks and financial institutions, which requires a series of strict Know Your Customer rules to be applied against criminal activity. A number of EU instructions are also used, such as European Union Regulation (EU) 961/2010 to implement restrictive measures against Iran, the document "Consensus on commitments stemming from European Regulation 1781/2006", which outlines ensuring equals terms and conditions between European payment service providers to verify payer information, uses appropriate customer data, due diligence measures and systems to prevent money laundering risk.

The Central Bank of Switzerland (SNB) does not carry out the direct oversight functions of individual players in the financial market; as an independent institute, SNB, however, is responsible for the overall stability of the system at the financial center. FINMA and SNB work closely together.

Under Article 19 of Law 951.11 on the Swiss National Bank ${ }^{17}$, in order to protect the stability of the financial system of thecountry, SNB controls the clearing system and the settlement of payments (payment systems) or agreements with financial instruments, in particular securities (securities management). SNB may also impose minimum requirements for payment systems or securities management to reduce the financial system stability risks(Article 20 of Law 951.11). Such requirements may, in particular, relate to the organizational framework, general conditions, operational safety, participants' admission to the system.

${ }^{17} 951.11$ Legge federale sulla Banca nazionale svizzera (Legge sulla Banca nazionale, LBN): http://www.admin.ch/opc/it/classified-compilation/20021117/index.html. 
The banking system of Japan is headed by the Central Bank - the Bank of Japan (BoJ), with 55\% of the public stock. The BA was created in 1882 for 30 years. Later, this term was extended for another 30 years, and in 1942 the bank was granted perpetuity and the monopoly right to issue banknotes ${ }^{18}$.

The activities of the Bank of Japan were established by a special Law on the Central Bank of Japan of 1942, which was renewed and agreed in 1979 with the law of 1942. The bank's capital stock was set at 100 million yen. And so far, it has not changed. $55 \%$ of the capital belongs to the state, $45 \%$ - to private shareholders (individuals, financial institutions, insurance companies, etc.). The shareholders were guaranteed a dividend of $4 \%$, which, with extremely high bank earnings, increased to $5 \%$. The rest of the income went to The Bank's activities include controlling the credit sector and overseeing the smooth operation of the payment and settlement systems by providing shortterm loans to credit institutions. The monetary policy of the Bank of Japan for several post-war decades was different from the one appied by the central banks of developed capitalist countries. For example, interest rate adjustments, minimum reserve policies and open market operations had little impact on the monetary market, and the Bank of Japan's primary monetary policy instrument was the direct quantitative limitation of loans under artificially low interest rates. In the mid 70's. The situation in Japan's economy has changed dramatically: a deep and long-term crisis came after high economic growth. With the changing phase of the economic cycle, the value of monetary regulation of the economy has risen very much because strengthening of the country`s positions in the banking system.

The Central Bank of France was established in January 18, 1800 by the first consul at the consulate of Napoleon Bonaparte, modeled on the Bank of England, first to be a regulator of the money-losing market and, second, to support the new currency. In line with the charter, written by Claude Perrier, the Bank of France has legally introduced itself as a limited liability company with a registered capital of 30 million. francs divided by 30 thousand shares, listed in total 1000 francs. 15 Regents and 3 Censors were represented by the shareholders. The governors' meeting forms the General Council, which elects the Central Committee (CC) - three members, including the president of the council. The Central Committee was responsible for all operations of the bank.

ACPR is a French supervisory authority, one of the bodies of the Central Bank of France19. ACPR is an independent administrative body without legal person, which oversees banks and insurance in France. It was established in January 2010 on the basis of Decree No. 2010-76, through the merger of the Banking Commission, Insurance Inspectorate (ACAM),

${ }^{18}$ Мельник П. В., Тарангул Л.Л., Гордей О.Д. Банківські системи зарубіжних країн. К. : Алерта, Центр учбової літератури, 2010. 589 с.

${ }^{19}$ Борисов А.Б. Большой экономический словарь. М. : Книжный мир, 2003. 895 с. 
Committee of Insurance Companies (CEA) and Committee on Credit Organizations and Investment Companies (CECEI).

This merger was created in accordance with Art. 152 of the Economy Modernization Act 2008 ACPR's mission is to "maintain the stability of the financial system and protect the clients, insurers, members and beneficiaries under its control" (Art. 612-120).

ACPR conducts a thorough study of accounting and prudential reports, quarterly or annually, as appropriate, internal control reports, solvency and reinsurance assessments. ACPR individually maintains and monitors insurance agencies. This allows for analysis and evaluation of the financial position of organizations.

On-site insurance, that is, ACPR conducts detailed oversight of the insurance agency to monitor the organization's activities. The determination of the on-site inspections depends primarily on the results and the quality of the organization's financial position reports. It may also depend on other parameters such as the number and content of insurers' requirements. On-site inspection conducts wide-range studies of detailed analysis of prudential and accounting reports, and ACPR seeks to provide a critical appraisal of the organizational functioning and the implementation of regulations.

Conducts the supervision and control over: the statute financing and compliance with prudential rules; management quality; management rules; insurance tools and procedures; risk management; the solvency of the organization as a whole.

The "Basic Principles for Effective Banking Supervision" issued by the Basel Committee is the most important standard in the area of banking regulation an supervision France. Therefore, these principles determine the general basis for ACPR, namely: normative and prudential claims; principles of management methods principles of powers among authorized bodies of authority.

The World Bank and the IMF have applied these principles in the framework of the financial sector assessment program (FSAP) or reports on the implementation of international standards and codes.

ACPR oversees: the General and Specialized Institutions Directorate (DCECGS) and the Investment Firm Association (DCEMEI). Within these two areas, three services have been created, which are grouped together: BNPP and SOCIETE GENERALE; CREDIT MUTUEL and CREDIT AGRICOLE; BPCE

${ }^{20}$ Article L612-1 Modifié par ORDONNANCE n 2014-1332 du 6 novembre 2014 art. 5: http://www.legifrance.gouv.fr/affichCodeArticle.do?idArticle=LEGIARTI000029722212\& cidTexte=LEGITEXT000006072026\&dateTexte=20150415\&oldAction=rechCodeArticle \& fastReqId=1277425731\&nbResultRech $=1$. 
Carried out the division in the areas of service provision: foreign banks; financing individuals and local communities; leasing and factoring; independent schools and private offices (located in France or Monaco); investment firms.

The financial sector is at risk of money laundering and terrorist financing. Therefore, ACPR operates under the Anti-Money Laundering and Terrorist Financing (LCB-FT) regulation. And like the Bulgarian National Bank, it executes, controls and supervises under Article L. 561-36 is responsible for compliance with persons under their obligations against money laundering and terrorist financing. ACPR is also in charge of implementing Regulation (EC) 1781/2006 on persons subject to obligations under European and national restrictive measures in the fight against terrorist financing.

Banking supervision in Italy is very multidimensional. It belongs to a "mixed" banking supervision strategy . Yes, it is implemented by the Central Bank and the Inter-Ministerial Committee on Credit and Savings. The latter is headed by the Minister of Finance, who can decide on his own if necessary. The Committee is mainly liable for compliance with credit law and for the protection of savings banks. The basic principles of banking supervision are formulated in the Law of the Italian Republic "On Banks", which was adopted in 1993. It defines the status of the bodies of banking and financial supervision and the procedure for its implementation, in particular, the National Commission for the Control of Financial Companies and the Stock Exchange, which controls the activity of credit institutions in the securities market ${ }^{21}$.

It should be stressed that there are many commonalities and distinctive features in the supervisory powers of the National Bank of Ukraine and the countries listed above. Bodies similar in their authority to the Council of the National Bank exist in many other countries . For instance, Germany has a similar Central Bank Board in charge, Monetary Policy Committee functions in Japan , and in Austria there`s a Board of Directors. There are similar bodies in the central banks of other foreign countries. They differ in structure and order of formation, scope of functions and powers. However, the principles of operation are characteristic of all, according to which only the basic, global issues of the activity of central banks are determined, without interfering in their operational activities.

There are several types of supervisiory organization. First, banking supervision can be carried out within the central bank (Italy, United Kingdom, Greece, Spain, Ukraine, Kazakhstan). The mixed banking supervision system assumes that the powers of banking supervision are shared between the central bank and the competent public authority (Germany, USA, France). The third type of banking supervision system in general excludes the participation of the

${ }^{21}$ Рождественская Т.Э. Теоретико-правовые основы банковского надзора в Российской Федерации : 12.00.14 : дис. ... д-ра юрид. наук. МГЮА, Москва, 2012. 432 с. 
central bank in this process: the banking supervisors are separated from the central bank (Switzerland, Canada, Sweden, Denmark, Austria).

Each state, at its discretion, organizes and exercises control over the sphere of financial services, taking into account the peculiarities of historical, economic, legal development, etc. What is common is that, to this end, special bodies (institutions, organizations) are usually created to deal with this particular issue, and that these issues are regulated at the highest legislative level. Bodies that exercise state control over financial services can be divided into those that exercise sole control over banking activities [these bodies (institutions) belong to central banks], as well as those that control various areas of financial services, including banking. There are various examples of such bodies. Yes, in the UK - the Financial Services Agency; in the US, the Federal Reserve, the Money Controller, the Federal Deposit Insurance Corporation, the Financial Control Service, 50 state banking departments; Ministry of Finance, Bureau of Financial Institutions Oversight in Canada.

The purpose of supervision and control in the Anglo-Saxon system was to gain a decent minimum capital stock. Moreover, as long as the reserve is sufficient to provide credit, liquidity can always be attained through the acquisition of broad and effective wholesale money markets. Given the availability of such financial liquidity, regulatory / banking authorities have allowed banks in all English-speaking countries to significantly reduce the liquidity of assets that occurred in the 1960s.

With sufficient physical assets and personal property of their own companies, the executives of large banks will never allow their institutions to run bankruptcy risks. Therefore, regulation may be based on general principles rather than obsessive intervention.

\section{Control and supervisory authorities of central banks of the countries with anglo-saxon legal system}

Anglo-Saxon free market agents emphasize that more direct public sector intervention into the banking sector leads to inefficiencies, generated by the allocation of resources that do not meet the interests of consumers; as well as to higher bad loans and corruption ${ }^{22}$. But it also greatly reduces the pressure on short-term profit maximization.

The closer and longer-lasting involvement of the public sector in banks also meant that external controls on the Anglo-Saxon system, such as transparent financial reporting and external surveillance, were not as well developed as in the Asian system.

${ }^{22}$ Гудхард Чарльз. Банки та керівні органи державного сектора економіки. Банки та банківські системи краӥн світу. Т. 2. № 4. 2009. С. 4-11. 
Each country had its own reasons for such an innovation, but the main one reflected in any decision is the need to control financial risks in a "single space". Moreover, these decisions were made not only by countries with traditionally developed financial markets, but also by so-called transition economy. It was in the latter case that not only the problem of controlling the risks differing in the peculiarity of "flowing" from one market segment to another, but also the need for parallel development of all spheres was keenly felt. The existence of significant imbalances (for example, between the development of the banking and insurance sectors) leads to the underdevelopment of the entire market as a whole. Moreover, one of the benefits of operating a mega-regulator is the ability to effectively control financial conglomerates that create "holding risks." Their disclosure and analysis is very complex, as each supervisory authority functions within its mandate and does not have a general picture of the financial crisis elements. Various regulatory and supervisory authorities, through the scope of their relatively narrow powers, also often shift their functions, leaving virtually unattended areas of financial intermediation. A single supervisory authority can provide a fairly flexible regulatory system. An important point is that with the development of a financial market that is subject to different levels of regulation and supervision, authorities, market participants - intermediaries - provide similar financial services, thus falling into inequal competitive conditions. It is common for all countries to establish a system of rules and regulations binding on commercial banks and a system to monitor their compliance.

All current banking systems in the world in the scientific literature are divided into several basic types. Each of the distinguished types is based on one of the main methods of banking supervision ${ }^{23}$ : - field inspection; analysis of external audit materials; - use of both external audit materials and own field audit materials; - stringent requirements for financial statements.

Outbound inspection - this is a feature of the United States banking system. In the United States, there is a mixed banking supervisory system whereby the Central Bank shares oversight responsibilities with other public authorities.

In the USA, several agencies carry out banking supervision within their competence - the Currency Control Office; Federal Deposit Insurance Corporation, Federal Reserve Bank, and State Governments ${ }^{24}$. Their powers include the following: liquidation of closed commercial banks; development of instructions, rules, instructions and regulations; taking preventive measures; advising the management of commercial banks; periodic comprehensive reviews of the status, operations and policies of subordinate commercial banks; generalization of reports and statistics of commercial banks.

\footnotetext{
${ }^{23}$ Костюченко О. А. Банківське право : підручник. К.: Професіонал, 2004. 544 с.

${ }^{24}$ Поллард А. М. Банковское право США. М. : Прогрес, 2002. 340 с.
} 
The agencies act as working groups, and the Federal agencies coordinate the proccess and develop standards for joint inspections.

In the United States, the current risk-based banking supervision model and it s as well being in place in Ukraine, combining visa-free supervision, regular meetings with commercial bank management, and inspection. In the beginning, the most risky areas of activity of a commercial bank are identified, then during the on-site inspection the bank's activity in these areas is checked, on the basis of which an overall assessment of the status of a particular commercial bank is presented. The components of such valuation differ depending on the type of financial institution (commercial bank, bank holding company; foreign bank branch, deposit bank).

When evaluating commercial banks, a structured rating system is used. The most well-known system that formalizes the results of such an inspection is CAMEL (Capital. Assets. Manegement. Earnings. Liquidity. - "Capital. Assets. Management. Profitability. Liquidity"), effective since 1979.

Throughout the history of developing and improving its own methodological approaches to the classification of credit institutions by groups of problems, the National Bank of Ukraine as a whole uses elements of the CAMEL model. Examples are the Provisional Procedure for Forming a Commercial Deposit Insurance Fund by Commercial Banks, approved by the National Bank of Ukraine Resolution No. 125 of May 28, 1996. The United States is the country with the largest number of commercial banks in the world (over five thousand). Naturally, the monitoring system of commercial banks decently differs from the supervision systems of countries where several dozen banks operate. Many commercial banks make it impossible to constantly check their operations on site, and supervisors are inevitably forced to rely more on remote inspection and the use of econometric methods. The monitoring of the financial condition of US commercial banks using computer systems is performed at intervals between on-site inspections.

The purpose of monitoring is to identify financial problems in the interval between inspections. The results are used to expedite checks at commercial banks with signs of deteriorating financial position to identify the weakest areas of activity of inspected commercial banks and to send the most experienced inspectors to troubled commercial banks.

The analysis of the bank's external audit material is characteristic of the United Kingdom. There is also the concept of oversight where supervisors are guided by the information of external auditors and carry out on-site inspections only in specific cases on a narrow range of issues. The Banking Supervision Authority of the UK is working closely with private audit firms. With such supervision, the banks are required to audit once every six months or once a year. In some cases, inspectors meet with auditors or bank management. The Central Bank of England receives and 
verifies certified annual external auditors as well as monthly or quarterly reports from commercial banks on solvency, liquidity of a commercial bank, open currency position and outstanding overdue loans, as well as concentration of credit risks. This type of supervision requires that the auditors immediately inform the supervisory authorities when identifying serious problems with the bank or banking law violation.

Given the importance of auditing in this type of oversight, supervisors should be able to influence the choice of auditors through a commercial bank. Typically, it is able to select an auditor from a list approved by the supervisory authorities and inform them when changing the auditor. In any case, the supervisory authorities have the option of removing the auditors or canceling the audit results if they consider the work performed by the auditors to be unsatisfactory.

There are no full-time inspectors in the UK, but the Bank of England is required to conduct periodic on-site inspections by commercial banks to assess specific areas of commercial bank activity or issues that have arisen.

It is noted in the scientific literature that another important feature of banking supervision in the UK and Germany is that they conduct on-site inspections also in order to evaluate and approve the internal control and audit system of a banking institution. The main task that is entrusted to the internal banking control of the supervisory body is to calculate the required level of capital depending on the risks that a commercial bank carries out in the course of its activity ${ }^{25}$.

\section{SUMMARY}

The article examines the supervisory powers of the central banks in the countries of the Romano-Germanic and Anglo-Saxon systems of law. It has been established that, in addition to the central bank, the supervision may be carried out by special agencies established under the auspices of the Treasury or independent institutions accountable to Parliament. The relevance of the study on supervisory powers is determined by European integration processes worldwide. It is substantiated that banking supervisors determine the scope, direction and method of audits, the form and content of audit reports, and provide audit organizations for the licensing. At the same time, the supervisory authorities have the right at any time to check the original documentation of the bank or to carry out certain researches and analysis of the bank's activity on their own.

${ }^{25}$ Латковська Т. А. Юридична категорія «банківська діяльність». «Наука і освіта 2005»: матеріали VIII Міжнар. наук.-практ. конф. Дніпропетровськ : Наука і освіта, 2005. Т. 45. Право. С. 65-68. 


\section{REFERENCES}

C. $37-38$.

1. Качан О.О. Банківське право.К. : Юрінком Інтер, 2000.

2. Костюченко О.А. Банківське право: Банківська система. Національний банк. Комерційні банки. Розрахунки і кредитування. Ринок цінних паперів. Національне валютне законодавство. Банківські системи зарубіжних країн. Інститут банківської таємниці : підручник. 3-тє вид. К. : Видавництво А.С.К., 2003. 928 с.

3. Поляков В.П., Московкина Л.А. Структура и функции центральных банков (зарубежный опыт) : учеб. пособ.М. : ИНФРА-М, 1995. $192 \mathrm{c}$.

4. Поляков В.П., Московкина Л.А. Структура и функции центральных банков (зарубежный опыт) : учеб. пособ.М. : ИНФРА-М, 1995. $192 \mathrm{c}$.

5. Міщенко В І. Центральні банки: організаційно-правові засади. К. : Тов. «Знання», 2004. 372 с.

6. Латковська Т.А. Основні функції центрального банку: проблеми визначення та класифікації. Актуальні проблеми держави $i$ права. 2011. Вип. 61. С. 218-227

7. R.K. "Regulation", «Global Legal Insights» 03/06/2013: http://www.globallegalinsights.com/practice-areas/banking-and-finance/ banking-regulation-1st-ed/germany.

8. The Lisbon Treaty Treaty on the Functioning of the European Union \& comments Part 3 / Union policies and internal actions Title VIII Economic and monetary policy (Articles 119-144) Chapter 2 - Monetary policy Article 127: http://www.lisbon-treaty.org/wcm/the-lisbon-treaty/treatyon-the-functioning-of-the-european-union-and-comments/part-3-unionpolicies-and-internal-actions/title-viii-economic-and-monetary-policy/chapter2-monetary-policy/395-article-127.htm.

9. DIRECTIVE 2006/48/EC OF THE EUROPEAN PARLIAMENT AND OF THE COUNCIL: http://eur-lex.europa.eu/legal-content/EN/TXT/ ?uri=CELEX:32006L0048.

10. DIRECTIVE 2006/49/EC OF THE EUROPEAN PARLIAMENT AND OF THE COUNCIL: http://eur-lex.europa.eu/legal-content/EN/TXT/ ?uri=celex:32006L0049.

11. Directive 2004/39/EC of the European Parliament and of the Council: http://eur-lex.europa.eu/legal-content/EN/TXT/?uri=celex:32004L0039.

12. DIRECTIVE 2007/64/EC OF THE EUROPEAN PARLIAMENT AND OF THE COUNCIL: http://eur-lex.europa.eu/LexUriServ/LexUriServ.do? uri=OJ:L:2007:319:0001:0036:en:PDF. 
13. DIRECTIVE 2009/110/EC OF THE EUROPEAN PARLIAMENT AND OF THE COUNCIL: http://eur-lex.europa.eu/LexUriServ/LexUriServ.do? uri=OJ:L:2009:267:0007:0017:EN:PDF.

14. DIRECTIVE 2009/65/EC OF THE EUROPEAN PARLIAMENT AND OF THE COUNCIL: http://eur-lex.europa.eu/LexUriServ/LexUriServ. do?uri=OJ:L:2009:302:0032:0096:en:PDF.

15. Gesetz über das Kreditwesen (Kreditwesengesetz - KWG): http://www.gesetze-im-internet.de/bundesrecht/kredwg/gesamt.pdf.

16. Law on the Bulgarian National Bank: http://www.bnb.bg/ bnbweb/groups/public/documents/bnb_law/laws_bnb_en.pdf

17.951.11 Legge federale sulla Banca nazionale svizzera (Legge sulla Banca nazionale, LBN): http://www.admin.ch/opc/it/classified-compilation/ 20021117/index.html.

18. Мельник П.В., Тарангул Л.Л., Гордей О.Д. Банківські системи зарубіжних країн. К. : Алерта, Центр учбової літератури, 2010. 589 с. / Борисов А.Б. Большой экономический словарь. М. : Книжный мир, 2003. 895 с.

19. Article L612-1 Modifié par ORDONNANCE n 2014-1332 du 6 novembre 2014 - art. 5: http://www.legifrance.gouv.fr/affichCodeArticle. do?idArticle=LEGIARTI000029722212\&cidTexte=LEGITEXT00000607202 $6 \&$ dateTexte $=20150415 \&$ oldAction $=$ rechCodeArticle $\&$ fastReqId $=127742573$ $1 \&$ nbResultRech=1.

20. Рождественская Т.Э. Теоретико-правовые основы банковского надзора в Российской Федерации : 12.00 .14 : дис. ... д-ра юрид. наук. МГЮА, Москва, 2012. 432 с.

21. Гудхард Чарльз. Банки та керівні органи державного сектора економіки .Банки та банківські системи країн світу. Т. 2. № 4. 2009. C. 4-11.

22. Костюченко О.А. Банківське право :підручник. К.: Професіонал, 2004. 544 с.

23. Поллард А.М. Банковское право США. М. : Прогрес, 2002. 340 с.

24. Латковська Т.А. Юридична категорія «банківська діяльність». «Наука і освіта - 2005»: матеріали VIII Міжнар. наук.-практ. конф. Дніпропетровськ : Наука і освіта, 2005. Т. 45. Право. С. 65-68.

Information about the author: Marushak A. V.,

Ph. D. in Law, Associate Professor, Chernivtsi Law Institute of the National University "Odessa Law Academy" 7, Skovorody str., Chernivtsi, 58000, Ukraine

ORCID ID: 0000-0002-4611-4906 